Proc. Estonian Acad. Sci. Eng., 2001, 7, 1, 5050-57

\title{
PERIODICAL COMPONENT OF THE WEST-ESTONIAN WIND
}

\author{
Teolan TOMSON
}

Estonian Energy Research Institute, Paldiski mnt. 1, 10137 Tallinn, Estonia; teolan@anet.ee

Received 28 September 2000, in revised form 16 November 2000

\begin{abstract}
Characteristics of the periodical component of the daily wind on the Estonian western coast have been established using the correlation analysis. The named component is known as coastal breeze occurring only in summer and it is always directed from the sea towards the land with the peak at 2 PM local time, independent from the cyclonic wind. Interrelation between the components of the wind, blowing parallel and crosswise to the coastline, decreases monotonously towards inland. Thus the breeze has no natural boundary and it is replaced smoothly by the local periodical wind of the same velocity while the prevailing direction of the latter is not transverse to the coast any more.
\end{abstract}

Key words: periodical wind, coastal breeze, correlation analysis.

\section{INTRODUCTION}

Due to the preparatory work for technical implementation of wind energy in Estonia, automatic measuring of wind parameters at the heights of 10 and $30 \mathrm{~m}$ with the interval of $10 \mathrm{~min}$ has started, although presently only at limited sites (Fig. 1), on the isle of Harilaid (HRL) and island of Kihnu (KHN). For the investigation of hourly increment of the wind velocity, the wind data have been measured at the height of $10 \mathrm{~m}$ with $30 \mathrm{~min}$ intervals at coastal airports in Kuressaare (KRS), Pärnu (PRN), and Tallinn (TLL) [ ${ }^{1}$. Figure 1 shows also the site of the single Estonian wind turbine on the Tahkuna Peninsula (THK) and the Nigula (NGL), Kuusiku (KSK), and Türi (TRI) Meteorological Stations where the data used in the present work have been measured at the height of $10 \mathrm{~m}$ with $3 \mathrm{~h}$ interval. Namely the periodical component is one of the dynamic characteristics of wind. Comparison of the data taken with $0.5 \mathrm{~h}$ and $3 \mathrm{~h}$ intervals shows that for the daily period, the data of meteorological stations are sufficient for the expected breeze analysis. However, they are insufficient for finding out 


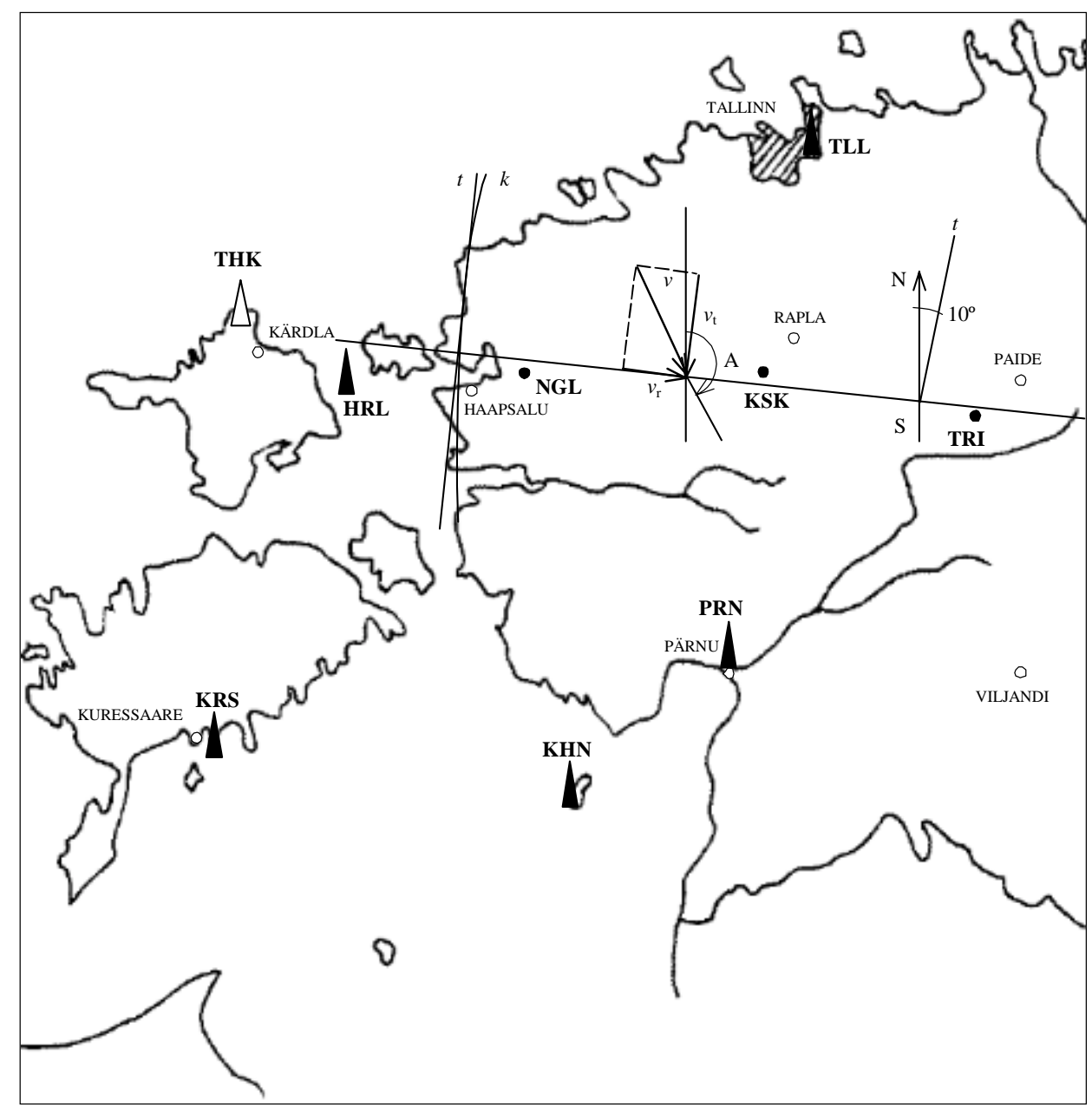

Fig. 1. Measuring sites of wind dynamics in Estonia.

several other dynamic characteristics of the wind. Let us mention that the databases have different lengths: at TLL data has been continuously recorded and analysed from 1 August to 31 December, 1998. All other sites (HRL, NGL, KSK, and TRI) have a continuous single month in the summer 1998, used for the analysis inside a longer simultaneously measured interval.

Wind has two significant periodical components: the yearly and the daily one. In the present work we focus on the second component quantitatively. Qualitatively the coastal breeze has been considered in many publications, cf. $\left[{ }^{2-4}\right]$. In these papers, for breeze observation only data for high-pressure days, when the cyclonic winds do not disturb periodical wind (mainly the breeze) caused by local convection, have been used. The main conclusion has been that the summer breeze is bidirectional (daytime sea breeze from the sea to the coast and nightly land breeze from inland to the sea) and it occurs in a relatively 
narrow (about $20 \mathrm{~km}$ wide) coastal zone. In this paper, for the investigation of the breeze, statistical methods, widely used in meteorology $\left[{ }^{5}\right]$, have been applied.

\section{METHOD OF ANALYSIS}

Correlation analysis of the measured wind data will be carried out treating wind velocity as a stationary random process. From the point of view of energy, the wind direction has no significance and if not referred to otherwise, the wind velocity is considered to be a scalar. The impact of the long (yearly) period appears as a trend for the 30-day analysis interval and has been screened off with the methods known in data processing $\left[{ }^{6}\right]$.

We can conclude on the basis of the calculated normalized autocorrelation functions $\rho(h)$, where the period of the periodic component is expressed in the actual scale (while the amplitude is somewhat distorted), that there is no periodical component on the sea (curve HRL in Fig. 2). The islet Harilaid lies $-40 \mathrm{~km}$ away from the coastline*. On the island of Kihnu, $-25 \mathrm{~km}$ from the coastline, the periodical component is hardly observable. It is known that the periodical component of the wind results from the local thermal convection of air and fades out towards winter. This statement is confirmed by the normalized autocorrelation functions of the wind in Tallinn, shown in Fig. 3. The $24 \mathrm{~h}$ periodical component is well observable in August and September and almost not observable in October. There is no periodical component in the autocorrelation functions of November and December winds. Figure 3 shows also another characteristic of wind dynamics: in winter the correlation time of wind velocity is longer and the exponential component of the autocorrelation function decreases more slowly. It means that stronger winds of the winter period are more stable

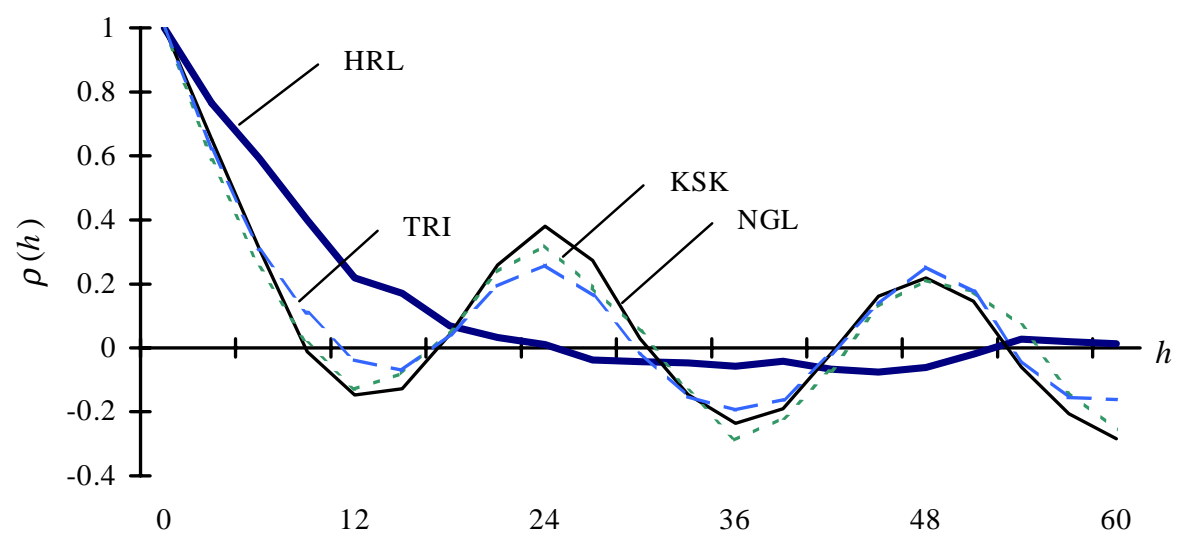

Fig. 2. Normalized autocorrelation functions of the wind velocity on the isle of Harilaid (HRL) and at Nigula (NGL), Kuusiku (KSK), and Türi (TRI).

\footnotetext{
* Distances from the approximated coastline towards inland sites have positive sign.
} 


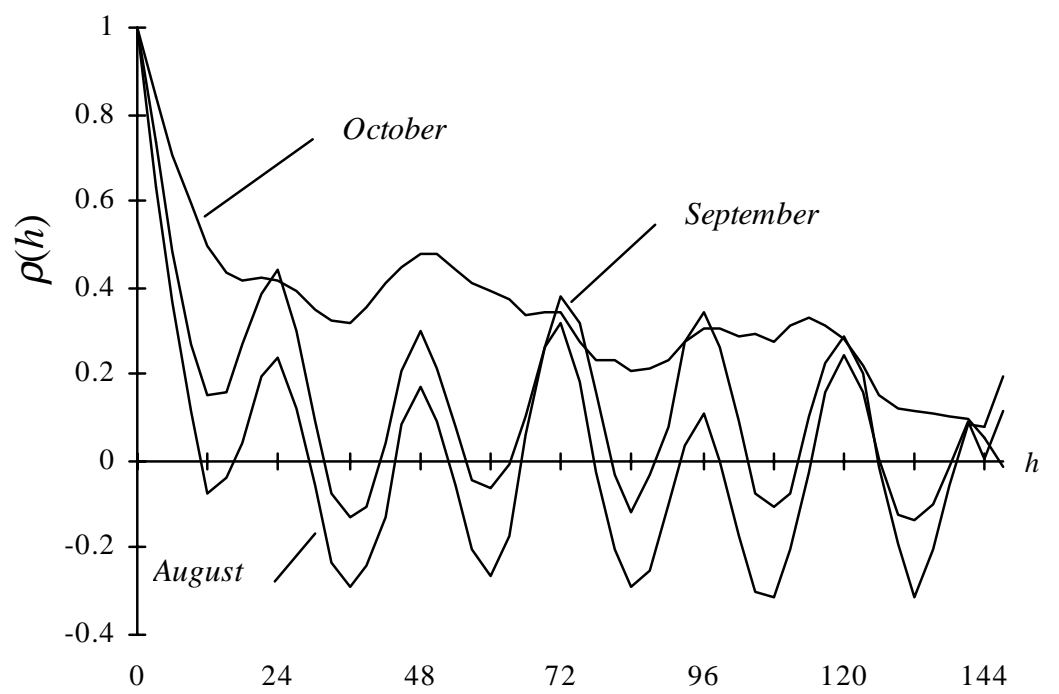

Fig. 3. The normalized autocorrelation functions of the wind in Tallinn in 1998.

from the point of view of their average value ${ }^{*}$ The data analysis shows that the correlation function does not depend on the height of the wind velocity sensor.

The $3 \mathrm{~h}$ measurement interval is too long to determine the phase of the periodical component of the wind (the peaks of the local wind velocity). Figure 4 shows daily wind dynamics in Pärnu for June-July and November-December, based on the $0.5 \mathrm{~h}$ data. In summer, the clear peak of wind velocity can be identified at about 2 PM (local time) that coincides with the outdoor temperature

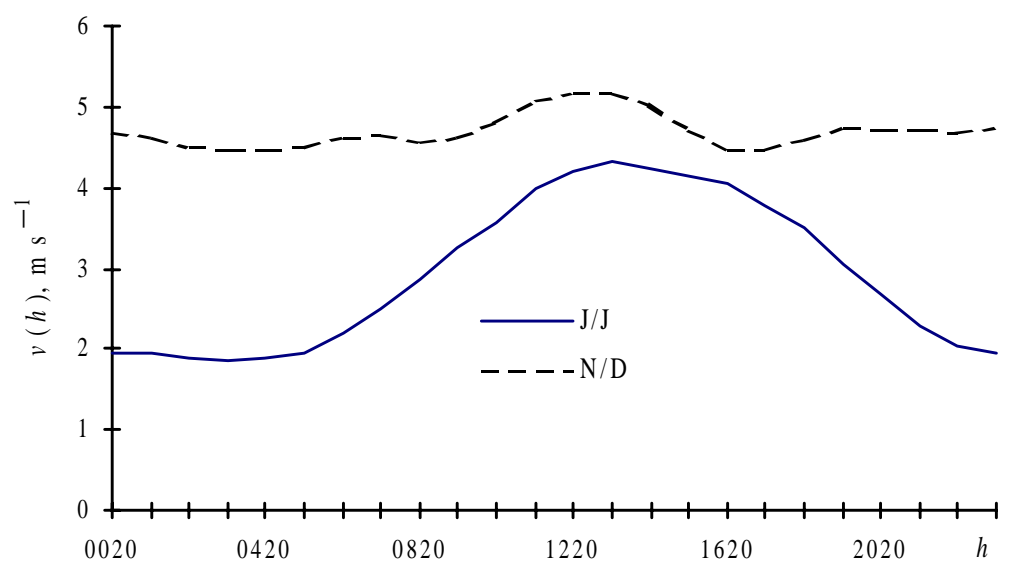

Fig. 4. Daily average wind velocity in Pärnu in June-July 1998 and November-December 1999.

\footnotetext{
* This statement is not valid for the instant value.
} 
peak and is similar to the data measured in Tartu $\left[^{7}\right]$. In winter, no clear daily maximum for the average wind velocity can be observed (an indistinct peak is at 12 AM).

The fact that the periodic component of wind has been observed also in Tartu, an inland site, raises the question about the scale of the expected breeze and its relation to other local winds. Another surprising fact is low dependence of the amplitude of the wind's periodical component on the distance from the coastline (Fig. 2). The impact of the sea should have vanished much faster according to the earlier investigations $\left[{ }^{2-4}\right]$.

\section{STRETCH OF THE BREEZE}

In order to find the relationship between the expected breeze and the local wind, also the correlation analysis was used, but for the wind velocity vector. Namely, for the period of analysis (August, 1998), the wind vector $v(h)$ at NGL, KSK, and TRI was split into two components (Fig. 1):

- radial component $v_{\mathrm{r}}=v(h) \sin \left(\mathrm{A}+10^{\circ}\right)$, in direction of the radius $r$ of the curve $k$ used for approximation of the coastline,

- tangential component $v_{\mathrm{t}}=v(h) \cos \left(\mathrm{A}+10^{\circ}\right)$, which follows the direction of the tangent to the coastline and intersects the radius.

The $10^{\circ}$ in the formulae is the azimuth of the tangential line (correction of the wind's measured azimuth $\mathrm{A}$ ).

The named measurement sites NGL, KSK, and TRI are located as close to the selected radial line $r$ as possible and their distances from the approximated coastline are approximately 20,70 , and $110 \mathrm{~km}$, respectively.

The work hypothesis is the following: the radial component of the wind vector is related to the movement of air between the sea and continent while the tangential component is not, i.e., fading away of the radial component (at least in comparison with the tangential component) shows the extension of the breeze towards the continent.

The normalized autocorrelation functions of the wind components are given for NGL and TRI (the most extraordinary examples) in Fig. 5.

From the normalized autocorrelation functions, the size of the amplitude of the periodical component can also be determined since at the moment $h=0$ normalized autocorrelation function $\rho(0)$ characterizes the dispersion of wind velocity $D$ (that can be found numerically from the measured data).

The amplitude of the periodical component can be calculated as

$$
v_{\mathrm{p}}=\sqrt{D \frac{\Delta \bar{\rho}_{\mathrm{m}}}{2}}
$$

where $\Delta \bar{\rho}_{\mathrm{m}}$ is the average difference of envelope curves of the normalized autocorrelation function $\rho(h)$. 

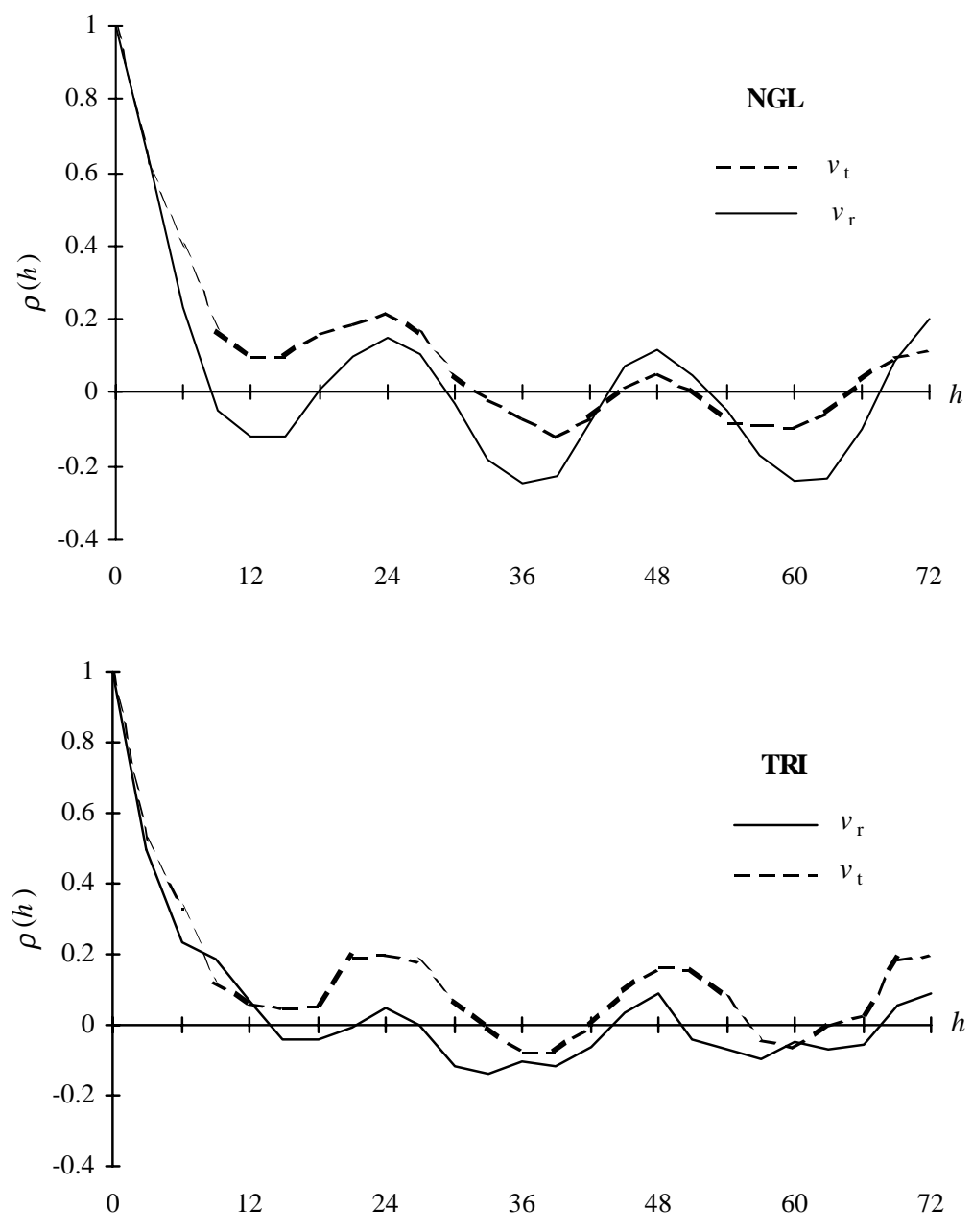

Fig. 5. Normalized autocorrelation functions of the radial $v_{\mathrm{r}}$ and tangential $v_{\mathrm{t}}$ wind components at Nigula (NGL) and Türi (TRI) in 1998.

Figure 6 shows the results. We can see that the average value of wind velocity on the open sea is much higher than that on the continent and it decreases further towards inland. The extremely low average value of wind velocity at KSK results from local hydraulic obstacles (sensor is surrounded by trees about $50 \mathrm{~m}$ away).

The ratio of amplitudes of the radial and tangential components decreases monotonously towards inland. If we define the coastal periodical wind as breeze and the inland periodical wind as non-breeze, we have to admit that the transition is barely noticeable and there is no natural boundary for the breeze. If somebody wants to draw a borderline, then it should be a line where the tangential component is equal to the radial one. In our example, the boundary line would be 


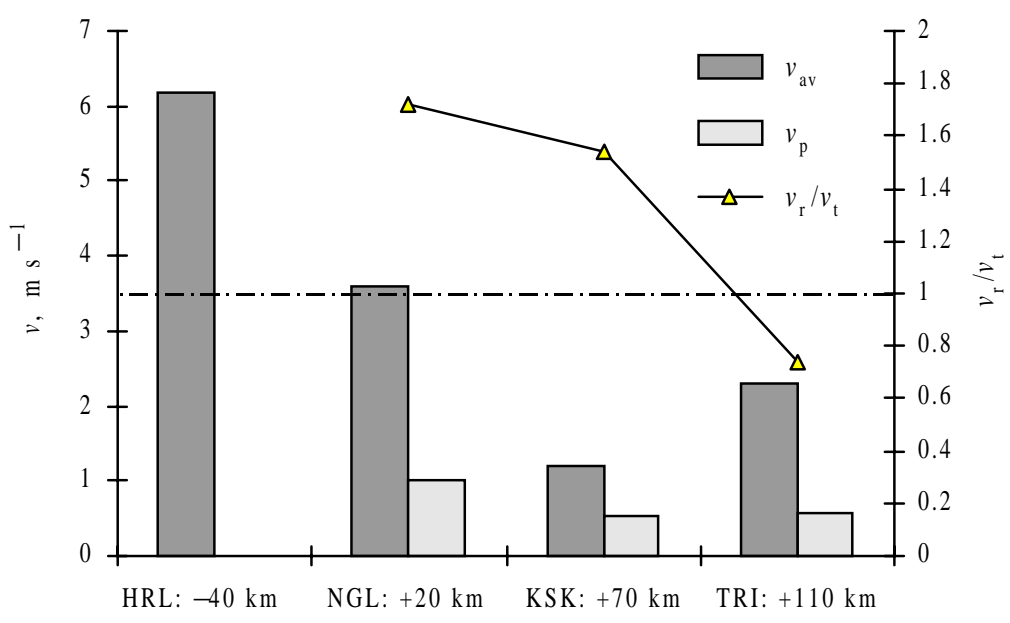

Fig. 6. The average of wind velocity $v_{\mathrm{av}}$, amplitude of the periodical component $v_{\mathrm{p}}$, and ratio of the radial and tangential velocity components $v_{\mathrm{r}} / v_{\mathrm{t}}$.

somewhere between 70 and $110 \mathrm{~km}$ from the coastline. It would be much further in the inland than stated in $\left[{ }^{2-4}\right]$.

\section{CONCLUSIONS}

In summer, the periodical component of wind (breeze on the coast) is always present independent of the velocity of the cyclonic wind. The latter is deformed by the breeze. If the breeze existed only in windless days, its amplitude would not be so high (about 30\% from the average wind).

The daily positive half-period of the periodical component is directed from the sea to the inland and complex wind at night can be in opposite direction only when amplitude of the periodical component exceeds the mean value of the wind. It means that from the statistical point of view, we cannot speak about land breeze in Estonia. If there occurs any, it would be an exception.

Main conclusions are the following.

- The periodical wind component at the coastal region can be observed only in summer.

- The value of its relative amplitude, about $30 \%$, is significant and this periodical wind blows from day to day.

- This phenomenon has no importance for energy production since the average summer wind velocity in Estonia, $4 \mathrm{~m} \mathrm{~s}^{-1}$, remains below the value by which the wind turbines start to generate energy. Periodical component is of importance by drawing a real wind velocity diagram which has both periodical and random components. 
- It is difficult to determine the fading of the breeze towards the continent; transition to the local periodical wind (non-breeze) is smooth.

- The velocity of non-breeze, a continental local wind in Estonia, is of the same magnitude as breeze on the seaside.

- In statistical meaning there is no land breeze in Estonia.

\section{ACKNOWLEDGEMENT}

The author expresses his thanks to Prof. Ants Meister, the TTU Institute of Radio Engineering, for consultations on data processing.

\section{REFERENCES}

1. Tomson, T. and Hansen, M. Performance of dissipated wind turbines. Proc. Estonian Acad. Sci., Eng., 2000, 6, 268-277.

2. Tarand, A. Kui kaugele merest ulatuvad briisid. Eesti Loodus, 1970, 1, 37-39.

3. Tarand, A. Tallinna briisid. Eesti Geograafia Seltsi aastaraamat 1971/72. Tallinn, 1974, 54-61.

4. Tarand, A. Impact of the Baltic Sea on the meteorological conditions in the zone close to the sea. In Dynamics of the Baltic Sea. Akad. Nauk ESSR, Tallinn, 1975, 103-113 (in Russian).

5. Tverskoj, N. Course of Meteorology: Physics of the Atmosphere. Gosgidrometeoizdat, Leningrad, 1962 (in Russian).

6. Bendat, J. and Pearson, A. Measurement and Analysis of Random Processes. Mir, Moscow, 1974 (in Russian).

7. Üld- ja agrometeoroloogia (Põiklik, K., ed.). Eesti Raamat, Tallinn, 1964.

\section{LÄÄNE-EESTI TUULE PERIOODILINE OSIS}

Teolan TOMSON

Suvel sisaldab Eesti tuul 24-tunnist perioodilist komponenti, mida kaldaribas on briisinähtusena seni ainult kvalitatiivselt uuritud. Mõõteandmete alusel leitud korrelatsioonifunktsioonid lubavad seda teha ka kvantitatiivselt. Selgub, et tuule perioodilise osise rannikuga ristise ja rannikuga paralleelse komponendi suhe väheneb monotoonselt sisemaa suunas ja briis läheb sujuvalt üle peaaegu sama suure amplituudiga kohalikuks perioodiliseks tuuleks, ilma et briisil oleks selgelt väljendatud ulatust. 12-tunnise perioodiga osise täielik puudumine vihjab sellele, et Eesti tingimustes maabriisi tema statistilises tähenduses ei eksisteeri. Seevastu on olemas merebriis tsüklonaalse tuule ligikaudu 30-protsendise osisena. Suvise tuule väikese keskmise kiiruse $\left(4 \mathrm{~m} \mathrm{~s}^{-1}\right)$ tõttu Lääne-Eesti tuule perioodilisel osisel tuuleenergeetika seisukohalt tähtsust ei ole. 